\title{
Field of Study and Transition into a Stable Job: The Case of a University in Southern Italy
}

\author{
Rosetta Lombardo (Corresponding author) \\ Department of Economics and Statistics, University of Calabria \\ Via P. Bucci, Cubo 0/C - 87036 Arcavacata di Rende (CS), Italy \\ E-mail: r.lombardo@unical.it \\ Giuliana De Luca \\ Department of Economics and Statistics, University of Calabria \\ Via P. Bucci, Cubo 0/C - 87036 Arcavacata di Rende (CS), Italy \\ E-mail: gideluca@unical.it \\ Giovanni Passarelli \\ Department of Sociology and Political Science, University of Calabria \\ Via P. Bucci, Cubo 0/B - 87036 Arcavacata di Rende (CS), Italy \\ E-mail: gpassarelli@unical.it
}

Received: October 31, 2011

Accepted: November 23, 2011

Published: February 1, 2012

doi:10.5539/ijef.v4n2p69

URL: http://dx.doi.org/10.5539/ijef.v4n2p69

\begin{abstract}
In this paper, we investigate the relationship between a graduate's field of study and probability of finding a stable job in a labor market which is flexible as regards atypical jobs but highly protective regarding stable jobs. We apply a discrete-time hazard model, taking into account unobservable heterogeneity, to analyze the transition to a stable job of students who graduated from the University of Calabria in 2004, at one, three and five years distance. Main findings indicate that, after controlling for a wide range of characteristics, Engineering graduates have a higher probability of finding a stable job than graduates in Economics and Business followed by those with a degree in Sciences, Political Science, and Humanities. These results confirm that, even in a deprived area, investing in occupational specific human capital can be seen as an "insurance" against the risk of unemployment or an unstable job.
\end{abstract}

Keywords: Discrete time hazard model, Graduate labor market, Stable job, Human capital

\section{Introduction}

The transition period from university to work is becoming longer and new cohorts of graduates face difficulties when looking for stable employment (Salas-Velasco, 2007). Difficulties in getting a job soon after graduation reveal structural problems of matching labor supply and demand. Such difficulties may generate long lasting unemployment, resulting in human capital depreciation which might affect an entire future professional career. In Italy, a number of studies have dealt with this subject (Ballarino and Bratti 2009; Biggeri et al., 2001; Pozzoli, 2009 among others) and several sample surveys have been conducted by single universities localized in central-northern regions of the country (Checchi, 2002; Staffolani and Sterlacchini, 2001 among others).

Italy is, in fact, characterized by some negative records: a high youth unemployment rate, a low female participation rate and a high rate of long-term unemployment. Regional disparities are anything but negligible: the northern part of the country has well-established traditions of private-sector entrepreneurship, while the southern part has long been dependent on the agricultural sector and government intervention. Unemployment is particularly concentrated in southern regions. In Calabria, for example, the youth unemployment rate in 2005 was $46,1 \%$, whereas it was 8,6\% in Trentino-Alto Adige. Among graduates aged 25-34, the unemployment rate in the same year was $28 \%$ in 
Southern Italy and 7\% in the North. Production structure, high reservation wages and widespread opportunities to do undeclared work are all elements that contribute to giving an explanation for the mass unemployment in the South.

Over the past two decades, Italy's labor market has been characterized by a transformation process aimed at increasing flexibility. Law 196/1997 represented a key step towards the liberalization of atypical contracts by introducing temporary contracts, providing incentives for part-time work, creating Temporary Work Agencies and loosening the regulations governing fixed-term contracts. Law 196/1997 was replaced by Law 30/2003 which introduced a number of new atypical job arrangements and reformed apprenticeships and temporary contracts. Deregulation of employment was expected to lower the unemployment levels through a reduction in the time spent searching for a first job. However, while flexibility has been introduced at the margin, having far-reaching consequences on unemployed and school leavers, it has left those in open-ended employment largely unaffected (Toharia and Malo, 2000). As a consequence of the partial and targeted deregulation, work contracts for new entrants have become less guaranteed, lower paid and less stable. There are widespread concerns that the new flexible jobs have increased labor market dualism between stable and unstable careers even among graduates.

In the South of Italy, additional factors, namely limits in growth capacity, in the options available to job seekers in the labor market (Note 1) and in the quality of the match between labor supply and labor demand, seem to contribute to the difficulties graduates encounter when looking for a stable job beyond those which are found in the new contractual arrangements (Reyneri, 2006).

Within this setting, we analyze the transition from university to stable job, be it subordinate or self-employment, using survey data for ex-students who graduated in 2004 from the University of Calabria, a university with around 35,000 enrolled students located in the southern Italian region of Calabria. More precisely, we address a research question dealing with the time which elapses between when a student gains a degree and when he/she obtains a stable job, focusing on the contribution the field of study makes to the speed of transition. Since the existing literature on transition to work is based entirely on national samples of graduates or samples of graduates from specific universities located in the Center-North, this is, to our knowledge, the first study focusing on graduates from a university located in an area of the South, with one of the highest graduate unemployment rates and with 10 percentage point lower possibility than in the northern areas of finding a steady job.

It is important to add this piece of research to the existing literature because of the significance given to stable jobs in the South of Italy, where, in a depressed labor market, a permanent job (the so called "posto fisso") is believed to guarantee the creation and reproduction of social relationships and that family security that is still so much more central - in terms of relative values - in the South than it is in the North. With this in mind, we apply a single-risk discrete time survival analysis accounting also for the unobserved heterogeneity between graduates. In this way we try to contribute to the understanding of whether the chance of finding a stable job by investing in occupational specific fields still exists.

The rest of the paper is organized as follows. In Section 2, we illustrate some interpretations of the relationship between field of study and labor market outcomes. Section 3 reviews the main empirical works on transitions in Italy. Section 4 presents data and methods and Section 5 shows the main empirical results. Section 6 concludes.

\section{Field of Study and Labor Market Outcomes: Some Interpretations}

In recent years, labor market outcomes (i.e. time to get the first job, employment probability, and earnings) have been discussed much more with relation to the level of education achieved than to the type of studies undertaken and yet field of study is a key determinant of individual labor market outcomes (Ballarino and Bratti, 2009). In turn, the individual preference for a field of study, as suggested by a body of work on educational choice (Dustmann, 2004; Montmarquette, 2002 among others), is influenced by family background, individual pre-existing ability and personality traits. These factors are also likely to influence individual labor market outcomes.

Several interpretations of the relationship between fields of study and labor market outcomes can be found in the literature. The latter generally divides fields of study into "quantitative" (hard fields), considered more occupational specific and "non-quantitative" (soft fields), considered less occupational specific and less challenging (Note 2) (Biglan, 1973).

The theory of human capital holds that education augments individual productivity and, therefore, earnings (Becker, 1975). In particular, certain fields of study may develop more productive skills than others (Paul and Murdoch, 2007). Furthermore, fields of study may differ in the extent to which they convey general versus occupation-specific skills, therefore, different fields of study may lead to different outcomes in terms of employability (Giesecke and Schindler, 2008). 
There is, however, an alternative line of thought (Spence, 1973; Arrow, 1973; Riley 2001) according to which higher levels of education are associated with higher earnings, because they signal job seekers' potential productivity rather than directly increasing it. In particular, by offering important signals of job seekers' potential productivity, fields of study allow employer's asymmetry of information regarding productivity and trainability to be overcome.

The field of study functions as a screening device because it also allows pre-existing differences in job seekers' talents and characteristics to be identified. In fact, ability distribution may be expected to differ across fields. Soft fields may rely less heavily than hard ones on prior ability so that less able students tend to select, or be selected for, less challenging fields than more able ones. This implies that less demanding fields carry a lower signal value in the labor market compared to more challenging fields (Reimer et al., 2008). It is worth noting that those wishing to start their own business do not need to signal anything. Hence, for them, education is a consumption good or an investment aimed at increasing productivity.

Furthermore, the individual's preference for a specific field of study may reflect his/her personality traits. The latter, in turn, represent a good predictor of job performance (McClelland, 1973; Semeijn et al., 2005).

In the light of these considerations, given that it is possible to get both specific and generic degrees in the Italian educational system, it is important to establish whether, in a "depressed" economy, a labor market which is flexible with regards atypical jobs and still highly protected for stable jobs favors the specific or the generic (Scherer, 2005).

On one hand, generic graduates might have low reservation wages and expectations and might be more willing to accept unstable/low paid jobs. Additionally, it is likely that labor market flexibility and the increasing importance of tertiary industries favor graduates with good communicative and relational skills, i.e. graduates in generic fields, as it is easier for them to enter the networks which characterize the core of the new economy (Ballarino and Bratti, 2009). Therefore, graduates in generic fields could have an advantage compared to graduates in specific ones in terms of speed, but not necessarily in terms of job quality.

On the other hand, we may expect fields classified as hard to affect positively the probability of finding a stable job thanks to at least four interconnected elements. First, hard fields are chosen by few students (Note 3). They are, in fact, considered difficult: students are required to attend lectures regularly, the workload is higher than in other subjects and final marks are generally lower (Note 4). Although industry in Italy, and in particular in the South, is specialized in traditional sectors characterized by small/medium size firms, low investment in research and innovation and, hence, low demand for high skilled and high specific human capital, specificity may still help in the search for a stable job because of the low number of graduates in hard fields.

Second, as it carries a signal of potentially high productivity, a degree in a hard field may raise the probability of getting a stable job.

Third, graduates from hard fields may need less training. The probability of finding a stable job is higher for labor market entrants who do not need to be trained. If occupational specificity is high, a training period may not be necessary and assessment may be immediate. By contrast, job and worker matching is more difficult if occupational specificity is low (Scherer, 2005).

Finally, graduates from hard fields may be assisted by those labor market conditions which are highly protective of stable jobs and that make subsequent corrections difficult. A high level of employment protection makes employers more cautious when creating new employment and filling vacancies. A high level of employment protection together with low specificity may bring about a delayed entry.

\section{The Empirical Evidence}

Entering the labor market successfully depends on coordination between the education system and the labor market which, in turn, improves matching between labor market supply and demand. In Italy, where there is no close coordination between the academic and the working worlds, evaluation of the observable (e.g. duration of an individual's university career, field of study, graduation marks, gender, graduate family background) and/or unobservable factors that influence the transition from university to work is crucial in the implementation of active policies.

A number of empirical studies have been carried out, at local and national levels, but few of them investigate explicitly the problem of the time which elapses between graduation and labor market entry.

Among the researchers who study the transition to the labor market of graduates from specific universities, Santoro and Pisati (1996) apply a continuous survival time Cox model and use a sample of students who graduated in 1993 from a university located in the Emilia-Romagna Region. Without explicitly taking into account unobserved 
heterogeneity between graduates, they find that the field of study and the final degree mark have significant effects on the probability of getting a job: graduates in Economics and Engineering have a higher chance of getting a job than graduates in Law and Humanities and students with better academic performance are more selective and postpone the transition to work. The authors do not find any statistical significance for the effect of variables such as high school type, age at graduation and family background.

Staffolani and Sterlacchini (2001) analyze the occupational outcomes of students who graduated in 1992 from four universities located in the Marche Region at three and five years after graduation. They find a statistically significant higher probability of obtaining a stable job for graduates in Electronic Engineering and Economics and Business and a lower probability for graduates in Mathematics, Science, Literature and Languages compared to Political Sciences.

Checchi (2002) and Checchi et al. (2004) analyze the occupational outcomes of graduates from the two big public universities in Milan, for the years 1997 and 1999, three years after graduation. They find that graduates in the Humanities are slower at finding their first job than graduates in Medicine, Pharmacy, and Science.

Among researchers who use specific waves of ISTAT (the Italian Statistical Institute) Graduates' Employment Survey data which gather evidence at a national level, Biggeri et al. (2001), focusing on the time taken to obtain a first job, evaluate the factors that determine the transition from university to work. By using a three level discrete-time survival model they find that the final mark has a positive effect on the probability of obtaining a first job after graduation, but they do not report results regarding fields of study. The occupational status and educational level of the student's parents are both significant: graduates have a higher probability of obtaining a job if at least one of their parents is working or if at least one of them has a secondary school certificate or a degree.

Using a multinomial logit model, Ballarino and Bratti (2009) find that, between 1995-2004, the best performing fields of study in terms of graduates' having found a stable job three years after graduation were and remain Hard Sciences, Hard Social Sciences and Technical, i.e. the quantitative, degrees.

By estimating an event history model of the time taken to obtain a stable job after graduation, Ballarino (2006) finds that graduates in technical-scientific subjects perform best from this point of view, closely followed by graduates in Economics, while graduates in Social Sciences, Education and Law do significantly worse.

Pozzoli (2009) estimates a discrete-time single-risk model to study employment hazard and test different specifications for individual unobserved heterogeneity distributions. He finds that the final mark does not have a statistically significant effect on the probability of getting the first job; parents' education and father's occupation have a positive effect on the graduates chance of employment. Older, female graduates, and those who graduated in the Humanities and Social Sciences have a lower hazard of obtaining their first job. Pozzoli also estimates a competing risk model and finds that age and work experience while at university have a negative effect on the hazard of exit from unemployment and that high school type and the final mark at university and school do not have statistically significant effects on the probability of finding an open-ended job. Having a father entrepreneur, manager, professional worker or white-collar worker increases the hazard rate of open-ended employment. Female graduates have a lower hazard of exit to open-ended employment than male graduates.

Among the researchers who use the Longitudinal Survey on Italian Families, Bernardi (2003) estimates an event history model for the whole Italian population of school-leavers from 1950 to 1990 using a piecewise constant exponential model with competing risk. He finds a general decrease in the impact of university degrees on the chance of getting a stable job and a constant advantage for Technical and Scientific graduates over Humanities graduates in the chance of finding a first stable job. Moreover, he finds that the transition into the labor market is more difficult for women and for residents of the Southern area; the class of origin has no consistent effect on the likelihood of finding a job as a dependent worker, but it plays a crucial role in the choice to become self-employed.

To summarize, previous research finds a better performance on the part of hard fields compared with soft ones in the university-to-work transition and no strong direct impact of family background on graduates' labor market outcomes.

We try to contribute to this literature by assessing the transition from university to stable job of graduates from a University in a southern Italian region characterized by difficult social and economic conditions, taking into account field of study along with observable individual and family characteristics and incorporating unobserved heterogeneity between graduates.

\section{Method and Data}

\subsection{Model Specification}

This paper considers survival analysis to study the occurrence and timing of finding a stable job. The event of interest (failure) occurs when a graduate finds a stable job. Transition may take place at any point in time but, as the 
follow-up is carried out at fixed intervals, the observed time $T$ for the $i$-th graduate $(i=1,2, \ldots, N)$ is known only to lie between two values $a_{i}$ and $b_{i}$. This type of data is also referred to as interval-censored survival data. To be more precise, for graduates who find a stable job between two interviews, all that is known is that "survival" time is at least as long as the time of the earlier interview and is no longer than the time of the more recent one. These observations are completed spell data. Instead, for those still not having found a stable job at their last follow up, all that is known is that their "survival" time is at least as long as the time associated with their last interview. These observations are right-censored. A censoring variable will let us know whether the transition to stable employment occurred $\left(c_{i}=1\right)$ or not $\left(c_{i}=0\right)$ in each time period.

Following the notation by Hosmer and Lemeshow (1999), it is assumed that there are $J+1$ intervals. More precisely, $I_{j}$ denotes the $j$-th time interval $\left(t_{j-1}, t_{j}\right]$ for $j=1,2, \cdots, J+1$ with $t_{0}=0$ and $t_{J+1}=\infty$, and these intervals are the same for all subjects. $y_{i j}$ is a binary variable indicating the specific time interval observed for the $i$-th subject, defined as equal to one if $\left(a_{i}, b_{i}\right]=I_{j}$ and zero otherwise.

The hazard of a graduate's finding a stable job in the $j$-th interval $I_{j}$ with $j=1,2, \cdots, J+1$, provided that he has not experienced the event in an earlier period, is thus given by (formulas are adapted from Hosmer and Lemeshow, 1999):

$$
\theta_{i j} \equiv \operatorname{Pr}\left[T \in\left(t_{j-1}, t_{j}\right) \mid T>t_{j-1}\right]=1-\exp \left[-\exp \left(x_{i}^{\prime} \beta+\tau_{j}\right)\right]
$$

where

$$
\tau_{j}=\ln \left\{-\ln \left[\frac{S_{0}\left(t_{j}\right)}{S_{0}\left(t_{j-1}\right)}\right]\right\}
$$

In this framework, our lower interval boundaries correspond to 2004, 2005 and 2007 whereas the upper interval boundaries correspond to 2005, 2007 and 2009, implying time intervals of unequal length $(0,1],(1,3],(3,5]$. Referring to our sample as a stock sample, $t_{0}=0$ represents the first observation of the stock sample when an individual is at risk of getting a stable job. At the end of a time period (for example after 1 year), some graduates will still not be working, will be in a fixed-term occupation (or will be lost to follow-up) whereas some will have found a stable job. The former, contributing right-censored spell data, are identified using censoring indicator $c_{i}=0$ and will be at risk of finding a stable job in the subsequent interval. By contrast, the latter, contributing to completed spell data, are identified by $c_{i}=1$ and will exit permanently from the analysis. More generally, the probability of survival until the end of the $j$-th interval is the product of the probabilities of not experiencing the event in each of the intervals up to and including the current one. For example, $S_{I_{3}}=$ (probability of survival through interval $\left.I_{1}\right)^{*}$ (probability of survival through interval $I_{2}$, given survival through interval $I_{1}$ )*(probability of survival through interval $I_{3}$, given survival through interval $I_{2}$ ). We rely on this framework to create person-period data so that each graduate contributes one record for each survey period, from immediately after his/her graduation up to the time of interview in which he/she finds a stable job, or the latest interview when he/she is observed (censoring due to loss to follow-up) or the 2009 interview if he/she never finds a stable job (administrative censoring).

The log-likelihood function can be written as a likelihood function for a binary regression model:

$$
l(\beta)=\prod_{i=1}^{n} \prod_{j=1}^{k i-1+q i}\left(1-\theta_{i j}\right)^{1-z i j} \theta_{i j}^{z i j}
$$

where $k_{i}$ is the observed interval for the $i$-th individual, that is $I_{k_{i}=}\left(a_{i}, b_{i}\right]$, and $z_{i j}=y_{i j} \times c_{i}$, that is a pseudo binary outcome variable. This version of the log-likelihood corresponds to the Prentice and Gloeckler model (1978). It is equivalent to the log-likelihood for a generalized linear model of the binomial family with a complementary log-log link (Jenkins, 1995). 
To describe unobserved (or omitted) heterogeneity between graduates, a Gamma distributed random variable $\varepsilon_{i}$, with unit mean and variance $\sigma^{2}=v$, is incorporated into the previous model [1]. The corresponding discrete-time hazard function is:

$$
\theta_{i j}=1-\exp \left\{-\exp \left[x_{i}^{\prime}+\tau_{j}+\log \left(\varepsilon_{i}\right)\right]\right\}
$$

Models are estimated using the pgmhaz 8 procedure developed by Jenkins (2004). We also estimate a fully non-parametric specification for the baseline hazard with duration dummies corresponding to each duration interval. This specification places no constraints on the shape of the baseline hazard function and is easily interpretable since each associated parameter represents hazard in time period $I_{j}$ for the baseline group (Note 5). Since the field of study effect may change over the period of follow up (i.e. non-proportionality of the effect), we also test for possible interaction between field of study and time. We estimate six specifications by progressively adding to the basic one (Model 1) including field of study and final marks (i.e. variables related to the university career), subsets of covariates according to the following pattern: individual demographic characteristic (Model 2), upper secondary school (Model 3), family background variables (Model 4), and graduates' searching behavior and work experience (Model 5). By comparing these specifications, we see whether the observed covariates at graduation influence the main effect of the field of study. Estimates are quite similar across all five model specifications. Besides the effect of factors at graduation which remain constant over the period of observation, we add two time-varying covariates to Model 6: the presence of children and the attendance of a master degree course. Results are relatively stable compared to the previous specifications. All models account for unobservable heterogeneity with a gamma distribution.

\subsection{Data}

Data used in this analysis come from the AlmaLaurea Interuniversity Consortium which covers over $75 \%$ of graduates from 64 Italian Universities. The dataset provides detailed retrospective information on students' characteristics such as academic performance, high school education, family background, labor market experience and job search activities.

Our sample of interest is defined as a stock-sample including all 2004 summer session graduates from the University of Calabria who declared their intention of searching for a job and not pursuing other studies to an end-of-university-career questionnaire organized via the Web. We follow them at one year (2005), three year (2007) and five year (2009) intervals after their graduation until they find a stable job or are censored. Finding a stable job is regarded as a permanent state (since it is open-ended), therefore, we only use information up to the year of the survey in which this occurs. As we are considering a follow up period of five years, the possibility of this assumption of irreversibility becoming unrealistic is unlikely to be a concern (Note 6).

Since we use data from one University only, this paper represents a case study. Although we do not claim it is representative of what happens to all Italian graduates, we think that the analysis is interesting since it is the first focusing on a context where the culture of the "posto fisso" is dominant and the economy is depressed.

The full 2004 sample included 1781 individuals. In 2005, 2007 and 2009 respectively, 1781, 1429 and 1421 questionnaires were completed. The associated response rates were approximately $89 \%, 84 \%$ and $77 \% .73 \%$ of respondents claimed to attribute great importance to the stability of the job while $46 \%$ of them declared not to attribute a great importance to coherence between their study subject and their future job. They did not have a preference regarding job sector.

For the present analysis, we drop those who did not take part in the first interview (11\%) and end up with a sub-sample of 1591 individuals. Furthermore, in order to only consider young people, we drop individuals who were aged over 35 at the time of graduation (4.2\%). Then, we drop those who found a stable job before graduation and were still doing the same job at the time of the first interview (4\%). Finally, we discard graduates who were not interested in finding a job (20\%), either because they declared their intention to continue studying in 2004 and had not changed their minds one year after graduation (confirmed by their declaration that they were not searching for a job) or for reasons other than studying. Therefore, our working sample consists of 1175 individuals $-743(63.2 \%)$ women and $432(36.8 \%)$ men. However, the length of follow up and rates of censoring cause effective sample sizes to differ from the number of baseline cases (Table 1). The percentages of subjects with a stable job are, respectively, about $12 \%, 18 \%$ and $25 \%$ in 2005, 2007 and 2009 for a total of 468 occupied in a stable job (failures). Excluding those who failed or were lost to follow-up, 1039 and 593 subjects are at risk in the second and third survey, respectively. 
The relevant questions considered in order to classify individuals according to their occupational status are the following: "Are you working at this moment?" and "If you are employed, what kind of contract do you have?". In order to identify individuals with a stable or atypical job, we rely on the AlmaLaurea classification based upon the self-reported current job contract. To be more precise, the former refers to both open-ended contracts and self-employment whereas the latter includes collaborators (often referred to as "co.co.co" contracts - contratti di collaborazione coordinata e continuativa) and those with fixed-term contracts, apprenticeships, no contract and others.

Table 2 provides summary statistics for the variables used in the analysis, separated according to gender. We group the fields of study into five categories, namely Engineering (Hard), Sciences including Pharmacy, Mathematics, Physics, Biology, Natural Sciences, Chemistry and Geology (Hard), Economics and Business (Hard Social Sciences), Humanities including Literature, Languages, History and Philosophy (Soft), and finally Political Science (Soft Social Sciences). Graduates in Engineering and Sciences represent respectively 16.3 and $14.2 \%$ of the whole sample whereas graduates in Economics and Business and in Political Science account respectively for 28.5 and 9.6\%. Finally students holding a degree in Humanities make up $31.3 \%$. Engineering is predominantly chosen by males. $38 \%$ of the sample obtains their degrees at the age of 27 or over. Most students have diplomas from Scientific and Technical high schools. Classical high school is predominantly chosen by females. With regards final marks, females generally perform slightly better than males both at school and university.

With regards family background as measured by father's occupational status and parents' education, $27 \%$ of the sample has a retired father whereas $86 \%$ come from a low educated family (Note 7 ). Most graduates express no preference regarding the type of work they are looking for, but three out of four of those who say they are searching in the public sector are females. Most of the sample has not had any previous working experience before graduation (Note 8).

Besides factors at graduation, the analysis also includes two time-varying covariates, namely having children ("children") and attendance of a course for a master's degree ("master attendance"). The former is an indicator variable which has value zero for interviews prior to its occurrence and one for the interviews after it occurred. Similarly, the latter takes a value of one if, during the follow-up, the individual gets a master's degree and zero otherwise.

\section{Results}

Table 3 presents estimated coefficients for a variety of individual and family variables and from separate complementary log-log models predicting stable jobs among 1,093 graduates aged under 35, who are searching for a job after graduation (Note 9). These account for a total of 2,286 person-periods at risk. The exponentiation of coefficients yields hazard ratios (HR).

Gamma variance parameter is not statistically significant for all specifications (Note 10). This finding may depend on the low number of time intervals which makes it difficult to distinguish frailty from duration dependence. Another possible explanation relates to the choice of the distributional shape for unobservable heterogeneity. For this reason, we also run a discrete mixture model using two mass points (Heckman and Singer, 1984) where the coefficient for the mass point for type one graduates is normalized to zero while the coefficient for the second mass point is estimated (Note 11). The model only converges for the least complex specifications (Models 1-3). The bulk of the probability mass is given to the second type (92\%). We can not reject the null hypothesis that the mass point for type two is not statistically different from the mass point for type one (the estimated mass point for type two is 12.86 with $p$-value 0.96 ).

Henceforward, we refer to exponentiated coefficients of Model 5, including predictors measured at graduation to interpret our results. Each figure illustrates the estimated step-shaped probability functions for significant predictors based on the fitted model 5 in Table 3. Values are obtained at the endpoints of each interval with functions between interviews assumed to be constant because of the interval censored data setting.

To check the robustness of our results, we estimate a multivariate probit model. The qualitative results for this model are comparable with those of the interval censored discrete time model. We again find a statistically significant association between field of study and the probability of finding a stable job (Note 12).

\subsection{The Role of Time Dependence}

In line with the results obtained by Pozzoli (2009), we discover that time has a positive effect on the probability of finding a stable job. This can be explained by the fact that, as time proceeds, individuals become increasingly informed about the availability of job opportunities, refine their search methods and increase their job search ability. Figure 1 illustrates the estimated baseline probability function. 


\subsection{The Role of the Field of Study}

Economics and Business graduates find a stable job at a rate that is about $52 \%$ ( $p$-value $<0.01$ ) lower than graduates in Engineering, followed by those with a degree in Sciences (about $62 \%, p$-value $<0.01$ ), Political Science (about $68 \%, p$-value $<0.01$ ) and Humanities (about $78 \%, p$-value $<0.01$ ). Besides, interaction between fields of study and time dummies does not turn out to be statistically significant, supporting the assumption of proportionality. Hence, it seems that individuals with generic occupational human capital are less likely to find a stable job compared to those whose human capital is more occupationally specific.

Figure 2 illustrates the estimated step-shaped failure functions for field of study. It shows how field of study affects the probability of having a stable job at 1, 3 and 5 years after graduation. At all times, the estimated probability of having a stable job is higher for graduates in Engineering. For the latter, the probabilities at one, three and five years distance are approximately 20,60 and 80\%, respectively. By contrast, for graduates in Humanities probabilities fall to nearly 5,17 and $30 \%$, respectively. The gap across fields of study generally becomes larger over time.

\subsection{The Role of Individual Characteristics}

Male graduates have a statistically significant higher hazard of stable employment compared with female graduates (HR 1.35, $p$-value $<0.01$ ). Graduates aged 23-24 and 25-26 exhibit a higher probability of finding a stable job than those aged over 27. Figures 3 and 4 illustrate the estimated step-shaped probability functions for gender and age groups, respectively. This finding might suggest that younger graduates (except the very young for whom the coefficient is not statistically different from those aged over 27) signal a superior (academic) ability as well as other non cognitive characteristics (self-esteem, motivation, personality and so on).

\subsection{The Role of Academic and School Performance}

There is no evidence of a direct effect of upper secondary school stream on the probability of finding a stable job. Final marks at school and at university are also found not to have an effect at any level of statistical significance. With regards these variables, the previous literature has not reached a definitive conclusion (Biggeri et al, 2001; Pozzoli, 2009). What is more, according to graduates, criteria such as personality and field of study seem to guide the recruitment of highly skilled workers by employers much more than the final mark in Italy (Rostan, 2006).

\subsection{The Role of Family Background}

Family background can capture the role of social networks in finding a job. Graduates with lowly educated parents and/or a retired/unemployed father may have less access to informal networks and, thus, have to wait longer to find a job. However, after controlling for a set of variables other than field of study, we find no evidence of a direct family background effect on the labor market outcome under investigation (Note 13). With regards these variables too there is mixed evidence in the literature (Biggeri et al, 2001; Pozzoli, 2009 among others).

\subsection{The Role of Other Relevant Variables}

We find weak evidence that those searching for a private job have a higher probability of finding a stable job compared to those searching for a public sector job (HR $1.39 p$-value $<0.1$ ). Those without work experience from before graduation have a $33 \%$ lower chance of finding a stable job (p-value $<0.01)$. It is likely that, in this latter case, solid networks have not been built yet. Model 6 shows that having attended a master degree course after graduation reduces the probability of graduates' finding a stable job (HR $0.82 p$-value $<0.1$ ). Finally, having children is associated with a lower hazard (HR $0.61 p$-value $<0.05$ ).

In Table 4, we try to account for the fact that having been employed in a temporary job may affect the chance of finding a stable one. With this aim, a variable, "atypical jobs", which takes a value of one if the individual acquires temporary work experience during follow-up and zero otherwise, is added to the final model. Results are relatively stable compared to the previous specifications except for some differences in the magnitude of the estimated coefficients and for the degree of positive duration dependence, which is larger. The gamma variance parameter is, in fact, statistically significant at $10 \%$ level. The main effects model (6a) in Table 4 shows that graduates with experience of fixed-term jobs during the follow up period exhibit a lower rate of finding a stable job, suggesting that intermittent contracts reduce the chance of finding a stable job. Despite this result, interaction model 6a shows that having had an atypical job mitigates the lower chance of finding a stable job for graduates in Economics and Business compared to graduates in Engineering. It is likely that, for these graduates, such contracts are designed to start them off on a career as an accountant (Note 14).

\section{Concluding Remarks}

In this paper, we try to shed some light on the role played by field of study in the finding of a stable job in a context where the culture of the "posto fisso" is dominant and the economy is depressed, controlling for a wide range of 
variables which may affect both student choice and employment outcomes. In line with previous literature, we find that the field of study matters in finding a stable job. In a context that combines flexibility and low occupational and training system specificity, it is likely that entry into the labor market will be delayed and result in an unstable career. That is the case for graduates in Economics and Business, Science, Political Science and especially Humanities. Conversely, where a high level of matching is immediately achievable through the presence of high vocational specificity, it is likely that entry into the labor market will occur earlier, resulting in a stable career. This is the case with Engineering. Therefore the choice of a hard field seems to be a good investment, one that acts as a form of insurance against the risk of unemployment or unstable careers.

Other notable results include a differential effect of gender, age, working experience before graduation, further investment in education, having children and having done temporary work during the follow up period. Family background and final mark at both school and at graduation do not turn out to have an effect on the probability of obtaining a stable job. This is not unexpected. In fact, although from a theoretical view these variables are recognized as important, no consistent results have been established in the empirical literature.

Based on these findings, we think that it is important to strengthen the connections between university and labor markets and carry out vocational projects within the degree courses. Consideration should also be given to the opportunity of combining degree study with work experience as part of the educational curriculum so as to improve the chance of finding a stable job without compromising educational performance. Despite the fact that a university's ultimate goal is providing high education and research, we argue that, in an area characterized by limited job opportunities and matching between labor demand and supply, the university should respond to society's needs and contribute to the area's development. This is true especially for a local university such as the one under consideration, i.e. attended by students who come predominantly from the region where the university is located and whose graduates often do not initially search for a job outside their region. For this reason, the university might provide career-related information to all students before they enter a field of study and inform prospective students about the labor market outcomes of graduates by field of study and unmet labor demand to minimize the risk of over-education and/or skill mismatch.

From a methodological view, an interval-censored discrete time hazard model is estimated. This approach is chosen to exploit both information gathered at each interview and the advantages of duration analysis (i.e. censoring, time dependence and unobservable heterogeneity). On the other hand, we are aware that the aggregation of the available data implies a loss of information, in particular exactly when someone makes the transition. Therefore, we think that asking about dates of transitions prior to interview, even on a sub sample, would enhance the usefulness of the data.

Deeper investigation of the sub-sample of the employed should be added to this work to complete the picture concerning relevant aspects such as earnings and job satisfaction. This step would shed some light on the effect of explanatory variables on the quality of stable jobs rather than merely on the probability of finding them. This is left for future research.

\section{Acknowledgements}

We are grateful to the administration of the University of Calabria for providing the authorization to use data, to Sara Laurita and Cinzia De Luca for providing access to the data. We would like to thank two anonymous referees, Giovanni Anania, Maurizio Franzini, Stefano Staffolani, Agostino Tarsitano and seminar participants at the 2010 SIE conference for useful comments and suggestions. The usual disclaimers apply.

\section{References}

AlmaLaurea. (2004). Occupational conditions of graduates: 2004 survey. Available at http://www.almalaurea.it (accessed 25 June 2010).

Arrow, K.J. (1973) Higher education as a filter. Journal of Public Economics, 2, 193-216. http://dx.doi.org/10.1016/0047-2727(73)90013-3

Ballarino, G. (2006). Stratificazione educativa e stratificazione sociale in Italia: il rendimento occupazionale del settore di studio universitario, in Scelte scolastiche e disuguaglianza sociale. Scelte individuali e vincoli sociali, (Eds.) G. Ballarino and Checchi, D., Bologna: il Mulino, pp. 137-179.

Ballarino, G., \& Bratti, M. (2009). Fields of study and university graduates' early employment outcomes in Italy during 1995-2004, Labour, 23, 421-457. http://dx.doi.org/10.1111/j.1467-9914.2009.00459.x

Becker, G.S. (1975). Human Capital, Chicago: University of Chicago Press.

Bernardi, F. (2003). Returns to educational performance at entry into the Italian labour Market. European Sociological Review, 9 (1):25-40. http://dx.doi.org/10.1093/esr/19.1.25 
Biggeri, L., Bini, M., \& Grilli, L. (2001). The transition from university to work: a multilevel approach to the analysis of the time to obtain the first job. Journal of the Royal Statistical Society, Series A (Statistics in Society), 164, 293-305. http://dx.doi.org/10.1111/1467-985X.00203

Biglan, A. (1973). The characteristics of subject matter in different academic areas. Journal of Applied Psychology, 57, 195-203. http://dx.doi.org/10.1037/h0034701

Bratti, M., Checchi, D., \& Filippin, A. (2007). Geographical differences in Italian Students' Mathematical Competences: Evidence from PISA 2003, Giornale degli Economisti e Annali di Economia, 66, 299-333.

Checchi, D. (2002). Formazione e percorsi lavorativi dell’Università degli Studi di Milano, Facoltà di Scienze Politiche, Unpublished paper No 14, University of Milan.

Checchi, D., Iacus S. M., Negri, I., \& Porro, G. (2004). Formazione e percorsi lavorativi dei laureati dell'Università degli Studi di Milano (II edizione: laureati 1999), Working Paper No. 04, University of Milan, Department of Economic, Business and Statistical Studies.

Dustmann, C. (2004). Primary to Secondary School Transitions, Parental Characteristics, and Career Patterns. Oxford Economic Papers, 56, 209-230. http://dx.doi.org/10.1093/oep/gpf048

Giesecke, J., \& Schindler, S. (2008). Field of Study and Flexible Work. A Comparative between Germany and the UK. International Journal of Comparative Sociology, 94, 283-304. http://dx.doi.org/10.1177/0020715208093078

Heckman, J.J., \& Singer, B. (1984). Econometric duration analysis. Journal of Econometrics, 24, 63-132. http://dx.doi.org/10.1016/0304-4076(84)90075-7

Hosmer, D. W. JR., \& Lemeshow, S. (1999). Applied Survival Analysis. Regression modelling of time to event data, New York: Wiley \& Sons.

ISTAT (2003). I laureati e il mercato del lavoro: Inserimento professionale dei laureati, Differenze territoriali, Indagine 2001, Roma, 2003. Available at http://www.Ista.it (accessed 11 May 2010).

Jenkins, SP. (1995). Easy estimation methods for discrete-time duration models. Oxford Bulletin of Economics and Statistics, 57, 129-138. http://dx.doi.org/10.1111/j.1468-0084.1995.tb00031.x

Jenkins, S.P. (2004). PGMHAZ8: Stata module to estimate discrete time (grouped data) proportional hazards models, Statistical Software Components S438501, Boston College Department of Economics. Available at http://ideas.repec.org/c/boc/bocode/s438501.html (accessed 31 May 2010).

McClelland, D.C. (1973). Testing for competence rather than for intelligence, American Psychologist, 28, 1-14. http://dx.doi.org/10.1037/h0034092

Montmarquette, C., Cannings, K., \& Mahseredjian, S. (2002). How do young People choose college majors?. Economics of Education Review, 21, 543-556. http://dx.doi.org/10.1016/S0272-7757(01)00054-1

Pozzoli, D. (2009). The transition to work for Italian university graduates, Labour, 23, 131-169. http://dx.doi.org/10.1111/j.1467-9914.2008.00442.x

Prentice, R., \& Gloeckler, L. (1978). Regression analysis of grouped survival data with application to breast cancer data, Biometrics, 34, 57-67. http://dx.doi.org/10.2307/2529588

Paul, J.-J., \& Murdoch, P. (2007). Study Content and Process, Competences Upon Graduation and Employment, in Careers of University Graduates: Views and Experiences in Comparative Perspectives, (Ed.) U. Teichler, Dordrecht: Springer, pp. 41-54.

Riley, J. G. (2001). Silver signals: twenty-five years of screening and signaling. Journal of Economic Literature, 39, 432-478. http://dx.doi.org/10.1257/jel.39.2.432

Reimer, D., Noelke, C., \& Kucel, A. (2008). Labor Market Effect of Field of Study in Comparative Perspective. International Journal of Comparative Sociology, 49, 233-256. http://dx.doi.org/10.1177/0020715208093076

Reyneri, E. (2006). Lavoro e Lavori nel Contesto Italiano, Diritti, lavori, mercati, 1, 1-12.

Rostan, M. (2006). Laureati italiani ed europei a confronto. Istruzione superiore e lavoro alle soglie di un periodo di riforme, Milano: LED.

Salas-Velasco, M. (2007). The transition from higher education to employment in Europe: the analysis of the time to obtain the first job, Higher Education, 54, 333-360. http://dx.doi.org/10.1007/s10734-006-9000-1

Santoro, M., \& Pisati, M. (1996). Dopo la laurea, Bologna: Il Mulino,. 
Scherer, S. (2005). Patterns of Labour Market Entry: long wait or career instability? An empirical comparison of Italy, Great Britain and West Germany. European Sociological Review, 21, 427-440. http://dx.doi.org/10.1093/esr/jci029

Semeijn, J., Boone, C., van der Velden, R., \& van Witteloostuijn, A. (2005). Graduates' personality characteristics and labor market entry an empirical study among Dutch economics graduates, Economics of Education Review, 24, 67-83. http://dx.doi.org/10.1016/j.econedurev.2004.03.006

Spence, M. (1973). Job market signaling. Quarterly Journal of Economics, 87, 355-374. http://dx.doi.org/10.2307/1882010

Staffolani, S., \& Sterlacchini, A. (2001). Istruzione universitaria, occupazione e reddito. Un'analisi empirica sui laureati degli atenei marchigiani, Milano: F. Angeli.

Toharia, L., \& Malo, M.A. (2000). The Spanish Experiment: Pros and Cons of the Flexibility at the Margin. In: G. Esping-Andersen and M. Regini (Eds.), Why Deregulate Labor Markets? Oxford: Oxford University Press.

\section{Notes}

Note 1. Factors such as corruption and organized crime may also act as a disincentive to job creation.

Note 2. Fields such as Engineering, Mathematics, Physics and Natural Science are classified as Hard. Business and Economics are often classified as Hard Social Sciences. Humanities and Law are classified as Soft. Political Science is often classified as Soft Social Science.

Note 3. A university reform (DM 509/99), implemented in the academic year 2001/2002, has introduced a switch from a one-level education system with just one degree to a structure including two levels: the first one lasts three years and the second ends after two additional years. By simplifying educational tracks, this reform could have influenced the choice of faculty leading new entrants to choose more challenging fields.

Note 4. The difficulty of scientific subjects partly stems from secondary school leavers' poor preparation in mathematics and science as confirmed by the standardized OECD's Programme for International Students Assessment (Bratti et al., 2007).

Note 5. We can not apply a competing risk analysis because it requires that all outcomes are final. More precisely, once one has occurred, the observation is over for that person and we can not use the occurrence of one type of event (e.g. atypical job) to predict a later one.

Note 6. In fact, some people with stable jobs may lose them. Given that one cannot rule out this possibility, in order to validate the assumption of irreversibility, it is opportune in our analysis to consider the event of interest as the finding of a "first" open-ended job.

Note 7. We are not able to use other measures of family background such as social class because of the high presence of missing values in these variables. However, even though social class is included it is not statistically significant.

Note 8 . Missing values in the variables used to measure family background, type of work searched and previous working experience account for less than $7 \%$ of the sample.

Note 9. We exclude from Model 1-3 anybody who is missing values for predictors on the following models to make the sample size the same. Nonetheless, there are no major differences in Models 1-3 that result from dropping the 82 individuals.

Note 10. Coefficients from the complementary log-log model without frailty are approximately the same as those from the model with frailty.

Note 11. The estimation uses Jenkins' hshaz module (Jenkins, 2004). Estimates are available upon request.

Note 12. The estimates are available upon request to the authors.

Note 13. The dataset also contains variables that describe the channels the graduates intend to utilize in their job search. The majority of them declare the intention of using all listed channels making this piece of information useless to build an indicator of the intensity of search. Nevertheless, we try to control for one channel that the literature recognizes as relevant in the job search, i.e. the recourse to informal networks (relatives and friends), but this turns out not to be statistical significant.

Note 14. The accounting profession is peculiar to Italy. To be a professional accountant an individual must pass the State examination and be registered in the roll of the competent local Ordine. After the graduation in Economics and Business, a prerequisite for sitting for the State examination is the completion of three years of apprenticeship in the office of a professional accountant. 
Table 1. Number of graduates at prior interview (risk set), outcomes and censoring at 1-year, 3-years and 5-years

\begin{tabular}{|l|c|c|c|c|c|c|}
\hline & \multicolumn{2}{|c|}{ 1-year } & \multicolumn{2}{c|}{ 3-years } & \multicolumn{2}{c|}{ 5-years } \\
\hline & N. & $\mathbf{\%}$ & N. & $\mathbf{\%}$ & N. & \% \\
\hline Risk set & 1175 & 100.00 & 1039 & 100.00 & 593 & 100.00 \\
\hline Open-ended contracts (event) & 136 & 11.60 & 186 & 18.00 & 146 & 24.60 \\
\hline Loss to follow up $^{\dagger}$ & - & - & 260 & 25.00 & 70 & 11.80 \\
\hline Without a job $^{\ddagger}$ & 638 & 54.30 & 285 & 27.40 & 181 & 30.60 \\
\hline Fixed-term contract $^{\ddagger}$ & 401 & 34.10 & 308 & 29.60 & 196 & 33.00 \\
\hline
\end{tabular}

Notes: ${ }^{\dagger}$ Censoring due to loss to follow-up may occur at each interview. ${ }^{\star}$ These subjects are censored at the time of the 5 -year interview.

Table 2. Sample summary statistics (Profile students survey 2004)

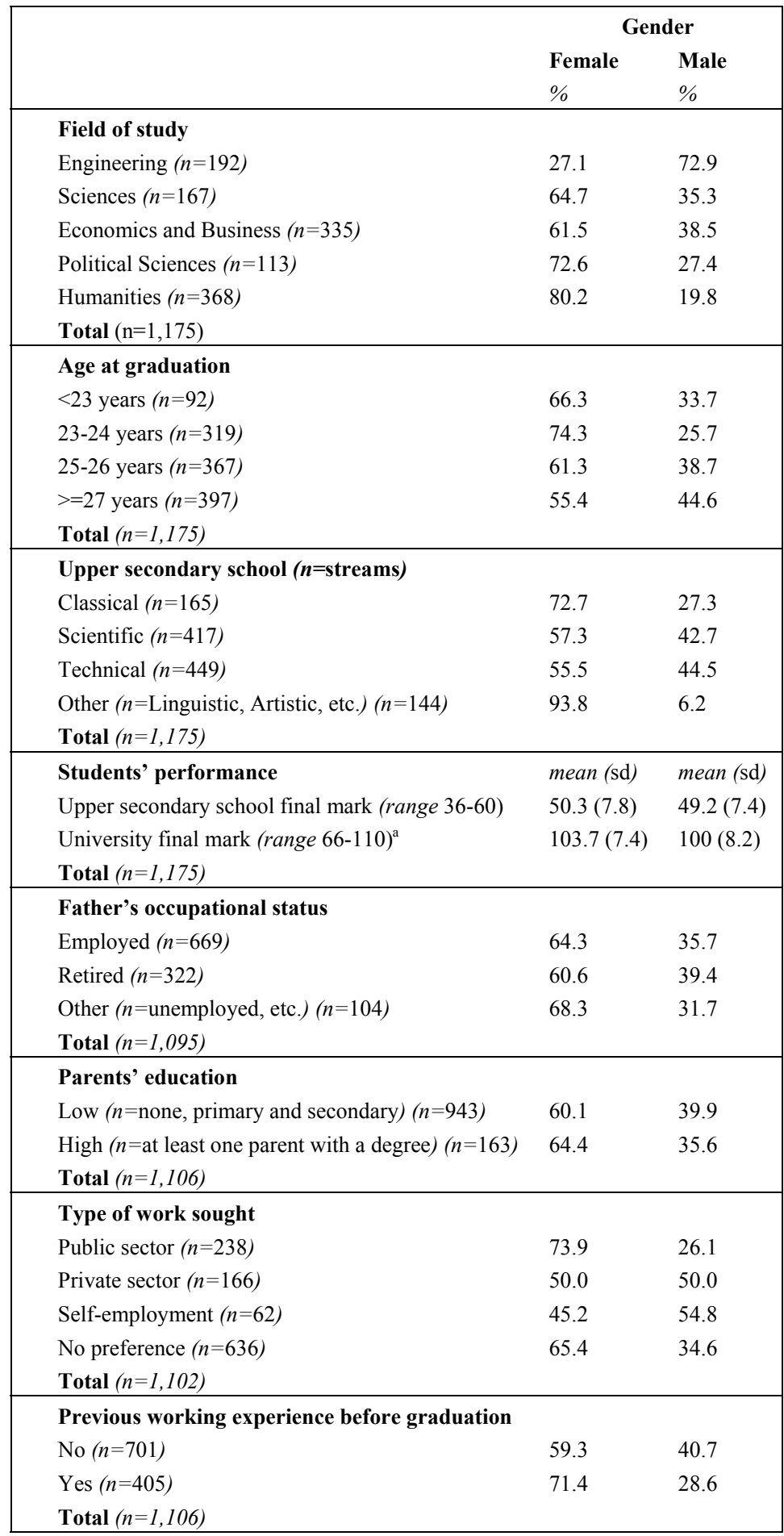

Note: ${ }^{\mathrm{a}}$ This piece of information is gathered in the subsequent survey. 
Table 3. Estimated coefficients and SEs based on the interval censored proportional hazard model

\begin{tabular}{|c|c|c|c|c|c|c|}
\hline & Model 1 & Model 2 & Model 3 & Model 4 & Model 5 & Model 6 \\
\hline & $\begin{array}{l}\text { Field of study and } \\
\text { academic } \\
\text { performance }\end{array}$ & $\begin{array}{l}\text { Demographic } \\
\text { characteristics }\end{array}$ & $\begin{array}{l}\text { Upper } \\
\text { secondary } \\
\text { school }\end{array}$ & $\begin{array}{c}\text { Family } \\
\text { background }\end{array}$ & $\begin{array}{l}\text { Work experience } \\
\text { and search } \\
\text { behavior }\end{array}$ & $\begin{array}{c}\text { Other controls } \\
\text { (Time varying } \\
\text { covariates) }\end{array}$ \\
\hline \multicolumn{7}{|l|}{$\begin{array}{l}\text { Time dependence (ref } \\
\text { Time interval } 1 \\
{[2004-2005)}\end{array}$} \\
\hline \multirow[t]{2}{*}{$\begin{array}{l}\text { Time interval } 2 \\
{[2005-2007)}\end{array}$} & $0.924 * * *$ & $0.874 * * *$ & $0.907 * * *$ & $0.918 * * *$ & $0.914 * * *$ & $0.971 * * *$ \\
\hline & $(0.155)$ & $(0.151)$ & $(0.152)$ & $(0.152)$ & $(0.147)$ & $(0.150)$ \\
\hline \multirow{2}{*}{$\begin{array}{l}\text { Time interval } 3 \\
{[2007-2009)}\end{array}$} & $1.199 * * *$ & $1.134 * * *$ & $1.200 * * *$ & $1.222 * * *$ & $1.215^{* * *}$ & $1.311 * * *$ \\
\hline & $(0.262)$ & $(0.251)$ & $(0.247)$ & $(0.244)$ & $(0.228)$ & $(0.234)$ \\
\hline \multicolumn{7}{|l|}{$\begin{array}{l}\text { Field of study (ref } \\
\text { Engineering) }\end{array}$} \\
\hline \multirow[t]{2}{*}{$\begin{array}{l}\text { Economics and Business } \\
\text { (Hard Social Science) }\end{array}$} & $-0.765 * * *$ & $-0.664 * * *$ & $-0.716^{* * *}$ & $-0.719 * * *$ & $-0.732 * * *$ & $-0.735^{* * *}$ \\
\hline & $(0.195)$ & $(0.179)$ & $(0.194)$ & $(0.197)$ & $(0.189)$ & $(0.189)$ \\
\hline Humanities (Soft) & $\begin{array}{c}-1.701 * * * \\
(0.250)\end{array}$ & $\begin{array}{c}-1.517 * * * \\
(0.229)\end{array}$ & $\begin{array}{c}-1.550 * * * \\
(0.257)\end{array}$ & $\begin{array}{c}-1.562 * * * \\
(0.258)\end{array}$ & $\begin{array}{c}-1.531 * * * \\
(0.247)\end{array}$ & $\begin{array}{c}-1.513 * * * \\
(0.243)\end{array}$ \\
\hline Sciences (Hard) & $\begin{array}{c}-0.986 * * * \\
(0.227)\end{array}$ & $\begin{array}{c}-0.894 * * * \\
(0.211)\end{array}$ & $\begin{array}{c}-0.983 * * * \\
(0.225)\end{array}$ & $\begin{array}{c}-0.976^{* * *} \\
(0.226)\end{array}$ & $\begin{array}{c}-0.963 * * * \\
(0.219)\end{array}$ & $\begin{array}{c}-0.991 * * * \\
(0.219)\end{array}$ \\
\hline \multirow{2}{*}{$\begin{array}{l}\text { Political Sciences (Soft } \\
\text { Social Science) }\end{array}$} & $-1.038 * * *$ & $-1.013 * * *$ & $-1.133 * * *$ & $-1.129 * * *$ & $-1.124 * * *$ & $-1.108^{* * *}$ \\
\hline & $(0.248)$ & $(0.237)$ & $(0.261)$ & $(0.263)$ & $(0.257)$ & $(0.256)$ \\
\hline $\begin{array}{l}\text { Academic performance } \\
\text { University final } \text { mark }^{\dagger}\end{array}$ & $\begin{array}{l}-0.001 \\
(0.007)\end{array}$ & $\begin{array}{l}-0.003 \\
(0.007)\end{array}$ & $\begin{array}{l}-0.000 \\
(0.008)\end{array}$ & $\begin{array}{c}0.000 \\
(0.008)\end{array}$ & $\begin{array}{c}0.002 \\
(0.008)\end{array}$ & $\begin{array}{c}0.005 \\
(0.008)\end{array}$ \\
\hline \multicolumn{7}{|l|}{$\begin{array}{l}\text { Demographic } \\
\text { characteristics } \\
\text { Gender (refFemale) }\end{array}$} \\
\hline $\begin{array}{l}\text { Gender (ref Female) } \\
\text { Male }\end{array}$ & & $\begin{array}{c}0.371 * * * \\
(0.120) \\
\end{array}$ & $\begin{array}{c}0.323 * * * \\
(0.121) \\
\end{array}$ & $\begin{array}{c}0.336 * * * \\
(0.120) \\
\end{array}$ & $\begin{array}{l}0.297 * * \\
(0.116) \\
\end{array}$ & $\begin{array}{l}0.276^{* *} \\
(0.116) \\
\end{array}$ \\
\hline \multicolumn{7}{|l|}{$\begin{array}{l}\text { Age at graduation }(\mathrm{ref} \geq \\
27 \text { years) }\end{array}$} \\
\hline$<23$ & & $\begin{array}{l}-0.620 \\
(0.425)\end{array}$ & $\begin{array}{l}-0.604 \\
(0.428)\end{array}$ & $\begin{array}{l}-0.624 \\
(0.431)\end{array}$ & $\begin{array}{l}-0.521 \\
(0.432)\end{array}$ & $\begin{array}{l}-0.582 \\
(0.433)\end{array}$ \\
\hline $23-24$ years & & $\begin{array}{c}0.375 * * * \\
(0.137)\end{array}$ & $\begin{array}{l}0.362 * * \\
(0.142)\end{array}$ & $\begin{array}{l}0.316^{* *} \\
(0.146)\end{array}$ & $\begin{array}{l}0.361^{* *} \\
(0.144)\end{array}$ & $\begin{array}{c}0.333 * * \\
(0.147)\end{array}$ \\
\hline $25-26$ years & & $\begin{array}{l}0.283 * * \\
(0.121) \\
\end{array}$ & $\begin{array}{c}0.299 * * \\
(0.127) \\
\end{array}$ & $\begin{array}{c}0.264 * * \\
(0.129) \\
\end{array}$ & $\begin{array}{c}0.264 * * \\
(0.126) \\
\end{array}$ & $\begin{array}{l}0.241^{*} \\
(0.127) \\
\end{array}$ \\
\hline \multicolumn{7}{|l|}{$\begin{array}{l}\text { Upper secondary school } \\
\text { streams (ref Scientific) }\end{array}$} \\
\hline Classical & & & $\begin{array}{l}-0.403^{*} \\
(0.220)\end{array}$ & $\begin{array}{l}-0.431^{*} \\
(0.222)\end{array}$ & $\begin{array}{l}-0.374 * \\
(0.220)\end{array}$ & $\begin{array}{l}-0.347 \\
(0.222)\end{array}$ \\
\hline Technical & & & $\begin{array}{l}-0.260 \\
(0.174)\end{array}$ & $\begin{array}{l}-0.250 \\
(0.176)\end{array}$ & $\begin{array}{l}-0.235 \\
(0.174)\end{array}$ & $\begin{array}{l}-0.247 \\
(0.175)\end{array}$ \\
\hline Other & & & $\begin{array}{l}-0.135 \\
(0.119)\end{array}$ & $\begin{array}{l}-0.143 \\
(0.122)\end{array}$ & $\begin{array}{l}-0.127 \\
(0.118)\end{array}$ & $\begin{array}{l}-0.118 \\
(0.120)\end{array}$ \\
\hline \multicolumn{7}{|l|}{ High school performance } \\
\hline High school final mark $\dagger$ & & & $\begin{array}{l}-0.011 \\
(0.008) \\
\end{array}$ & $\begin{array}{l}-0.010 \\
(0.008) \\
\end{array}$ & $\begin{array}{l}-0.010 \\
(0.008) \\
\end{array}$ & $\begin{array}{l}-0.010 \\
(0.008) \\
\end{array}$ \\
\hline \multicolumn{7}{|l|}{$\begin{array}{l}\text { Family background } \\
\text { Father's occupational } \\
\text { status (ref employed) }\end{array}$} \\
\hline Retired & & & & $\begin{array}{l}-0.182 \\
(0.122)\end{array}$ & $\begin{array}{l}-0.160 \\
(0.122)\end{array}$ & $\begin{array}{l}-0.184 \\
(0.122)\end{array}$ \\
\hline Other & & & & $\begin{array}{l}-0.251 \\
(0.198)\end{array}$ & $\begin{array}{l}-0.262 \\
(0.197)\end{array}$ & $\begin{array}{l}-0.247 \\
(0.198)\end{array}$ \\
\hline \multicolumn{7}{|l|}{$\begin{array}{l}\text { Parents education (ref } \\
\text { high education) }\end{array}$} \\
\hline Low education & & & & $\begin{array}{c}0.212 \\
(0.148)\end{array}$ & $\begin{array}{c}0.151 \\
(0.147)\end{array}$ & $\begin{array}{c}0.130 \\
(0.148)\end{array}$ \\
\hline
\end{tabular}


Table 3 (Continued). Estimated coefficients and SEs based on the interval censored proportional hazard model

\begin{tabular}{|c|c|c|c|c|c|c|}
\hline & Model 1 & Model 2 & Model 3 & Model 4 & Model 5 & Model 6 \\
\hline & $\begin{array}{l}\text { Field of study and } \\
\text { academic } \\
\text { performance }\end{array}$ & $\begin{array}{l}\text { Demographic } \\
\text { characteristics }\end{array}$ & $\begin{array}{l}\text { Upper } \\
\text { secondary } \\
\text { school }\end{array}$ & $\begin{array}{c}\text { Family } \\
\text { background }\end{array}$ & $\begin{array}{l}\text { Work experience } \\
\text { and search } \\
\text { behavior }\end{array}$ & $\begin{array}{l}\text { Other controls } \\
\text { (Time varying } \\
\text { covariates) }\end{array}$ \\
\hline \multicolumn{7}{|l|}{$\begin{array}{l}\text { Search behavior (ref } \\
\text { public) }\end{array}$} \\
\hline Private (job sought) & & & & & $\begin{array}{l}0.333^{*} \\
(0.176)\end{array}$ & $\begin{array}{l}0.340^{*} \\
(0.178)\end{array}$ \\
\hline \multirow{2}{*}{$\begin{array}{l}\text { Self-employment (job } \\
\text { sought) }\end{array}$} & & & & & 0.023 & 0.033 \\
\hline & & & & & $(0.251)$ & $(0.252)$ \\
\hline \multirow{2}{*}{$\begin{array}{l}\text { No preference (job } \\
\text { sought) }\end{array}$} & & & & & 0.123 & 0.129 \\
\hline & & & & & $(0.145)$ & $(0.145)$ \\
\hline \multirow{3}{*}{$\begin{array}{l}\text { Work experience } \\
\text { No previous work } \\
\text { experience }\end{array}$} & & & & & & \\
\hline & & & & & $-0.396 * * *$ & $-0.404 * * *$ \\
\hline & & & & & $(0.115)$ & $(0.116)$ \\
\hline \multicolumn{7}{|l|}{$\begin{array}{l}\text { Other controls (Time } \\
\text { varying covariates) }\end{array}$} \\
\hline \multirow[t]{2}{*}{$\begin{array}{l}\text { Master attendance (ref no } \\
\text { attendance) }\end{array}$} & & & & & & $-0.200^{*}$ \\
\hline & & & & & & $(0.120)$ \\
\hline Children (ref no children) & & & & & & $\begin{array}{c}-0.490 * * \\
(0.249)\end{array}$ \\
\hline \multirow[t]{2}{*}{ Constant } & $-1.235 * * *$ & $-1.655^{* * *}$ & $-1.467 * * *$ & $-1.550 * * *$ & $-1.534 * * *$ & $-1.449 * * *$ \\
\hline & $(0.174)$ & $(0.171)$ & $(0.193)$ & $(0.239)$ & $(0.283)$ & $(0.285)$ \\
\hline Observations & 2,286 & 2,286 & 2,286 & 2,286 & 2,286 & 2,286 \\
\hline Gamma variance & 0.095 & 0.006 & 0.082 & 0.093 & 0.042 & 0.063 \\
\hline SE Gamma var. & 0.333 & 0.302 & 0.293 & 0.286 & 0.250 & 0.243 \\
\hline
\end{tabular}

Notes: SEs in parentheses. ${ }^{* * *} p$-value $<0.01,{ }^{* *} p$-value $<0.05,{ }^{*} p$-value $<0.1$. Estimates account for unobservable heterogeneity (Gamma distribution). $\dagger$ Final marks are centered at their mean. Dummies variables for each province were also included in the complete models to take into account local labor market factors.

Table 4. Estimated coefficients and SEs based on the interval censored proportional hazard model

\begin{tabular}{|lcc|}
\hline & Model 6a & Model 7 \\
\hline & $\begin{array}{c}\text { Other controls } \\
\text { (Time varying } \\
\text { covariates "Atypical") }\end{array}$ & $\begin{array}{c}\text { Interaction between } \\
\text { "Atypical" and field of } \\
\text { study }\end{array}$ \\
\hline Time dependence (ref Time interval 1 [2004-2005)) & $1.659^{* * *}$ & $1.597^{* * *}$ \\
Time interval 2 [2005-2007) & $(0.294)$ & $(0.251)$ \\
Time interval 3 [2007-2009) & $2.545^{* * *}$ & $2.362^{* * *}$ \\
& $(0.521)$ & $(0.430)$ \\
\hline Field of study (ref Engineering) & $-1.316^{* * *}$ & $-1.594^{* * *}$ \\
Economics and Business (Hard Social Science) & $(0.276)$ & $(0.297)$ \\
& & $0.886^{* * *}$ \\
Interaction between Economics and Business and Atypical & $-2.116^{* * *}$ & $(0.340)$ \\
& $(0.347)$ & $-2.313^{* * *}$ \\
Humanities (Soft) & & $(0.357)$ \\
Interaction between Humanities and Atypical & $-1.488^{* * *}$ & $0.664^{*}$ \\
Sciences (Hard) & $(0.300)$ & $(0.364)$ \\
Interaction between Sciences and Atypical & & $-1.713^{* * *}$ \\
Political Sciences (Soft Social Science) & & $(0.325)$ \\
Interaction between Political Sciences and Atypical & $-1.701^{* * *}$ & 0.677 \\
& $(0.354)$ & $(0.430)$ \\
University final mark & & $-1.921^{* * *}$ \\
& & $(0.380)$ \\
\end{tabular}


Table 4(continued). Estimated coefficients and SEs based on the interval censored proportional hazard model

\begin{tabular}{|c|c|c|}
\hline & Model 6a & Model 7 \\
\hline & $\begin{array}{c}\text { Other controls } \\
\text { (Time varying } \\
\text { covariates "Atypical") }\end{array}$ & $\begin{array}{l}\text { Interaction between } \\
\text { "Atypical" and field of } \\
\text { study }\end{array}$ \\
\hline \multicolumn{3}{|c|}{ Demographic characteristics (ref Female, $\geq 27$ years) } \\
\hline Male & $\begin{array}{c}0.385^{* *} \\
(0.166)\end{array}$ & $\begin{array}{c}0.380^{* *} \\
(0.154)\end{array}$ \\
\hline$<23$ & $\begin{array}{l}-0.917^{*} \\
(0.507)\end{array}$ & $\begin{array}{l}-0.928^{*} \\
(0.488)\end{array}$ \\
\hline $23-24$ years & $\begin{array}{c}0.394 * * \\
(0.197)\end{array}$ & $\begin{array}{c}0.370 * * \\
(0.185)\end{array}$ \\
\hline $25-26$ years & $\begin{array}{l}0.318^{*} \\
(0.175)\end{array}$ & $\begin{array}{l}0.306^{*} \\
(0.164)\end{array}$ \\
\hline \multicolumn{3}{|c|}{ Upper secondary school (streams) (ref Scientific) } \\
\hline Classical & $\begin{array}{l}-0.403 \\
(0.283)\end{array}$ & $\begin{array}{l}-0.373 \\
(0.266)\end{array}$ \\
\hline Technical & $\begin{array}{l}-0.379 \\
(0.236)\end{array}$ & $\begin{array}{l}-0.352 \\
(0.222)\end{array}$ \\
\hline Other & $\begin{array}{l}-0.159 \\
(0.169)\end{array}$ & $\begin{array}{l}-0.152 \\
(0.158)\end{array}$ \\
\hline High school final mark ${ }^{\dagger}$ & $\begin{array}{l}-0.015 \\
(0.012)\end{array}$ & $\begin{array}{l}-0.013 \\
(0.011)\end{array}$ \\
\hline \multicolumn{3}{|c|}{ Family background (ref employed, high education) } \\
\hline Retired (father's occupational status) & $\begin{array}{l}-0.226 \\
(0.161)\end{array}$ & $\begin{array}{l}-0.207 \\
(0.151)\end{array}$ \\
\hline Other (father's occupational status) & $\begin{array}{l}-0.371 \\
(0.262)\end{array}$ & $\begin{array}{l}-0.345 \\
(0.248)\end{array}$ \\
\hline Low education (parents) & $\begin{array}{c}0.135 \\
(0.205) \\
\end{array}$ & $\begin{array}{c}0.125 \\
(0.192) \\
\end{array}$ \\
\hline \multicolumn{3}{|l|}{ Work experience and search behavior } \\
\hline Private (job sought) (ref public) & $\begin{array}{c}0.569^{* *} \\
(0.249)\end{array}$ & $\begin{array}{c}0.524 * * \\
(0.231)\end{array}$ \\
\hline Self-employment (job sought) (ref public) & $\begin{array}{l}-0.002 \\
(0.346)\end{array}$ & $\begin{array}{c}0.021 \\
(0.323)\end{array}$ \\
\hline No preference (job sought) (ref public) & $\begin{array}{c}0.232 \\
(0.193)\end{array}$ & $\begin{array}{c}0.228 \\
(0.181)\end{array}$ \\
\hline No previous work experience & $\begin{array}{c}-0.573 * * * \\
(0.159)\end{array}$ & $\begin{array}{c}-0.535^{* * *} \\
(0.150)\end{array}$ \\
\hline \multicolumn{3}{|l|}{ Other controls (Time varying covariates) } \\
\hline Master attendance & $\begin{array}{c}-0.276^{*} \\
(0.164)\end{array}$ & $\begin{array}{c}-0.259 * \\
(0.153)\end{array}$ \\
\hline Children & $\begin{array}{c}-0.692 * * \\
(0.315)\end{array}$ & $\begin{array}{c}-0.662 * * \\
(0.297)\end{array}$ \\
\hline Atypical jobs & $\begin{array}{c}-1.254 * * * \\
(0.275)\end{array}$ & $\begin{array}{c}-1.736^{* * *} \\
(0.338)\end{array}$ \\
\hline Constant & $\begin{array}{l}-0.768^{*} \\
(0.420)\end{array}$ & $\begin{array}{l}-0.639 \\
(0.399)\end{array}$ \\
\hline Observations & 2,286 & 2,286 \\
\hline Gamma variance & $1.113^{*}$ & $0.838^{*}$ \\
\hline SE Gamma variance & 0.622 & 0.500 \\
\hline
\end{tabular}

Notes: $\mathrm{SE}$ in parentheses. $* * * p$-value $<0.01, * * p$-value $<0.05, * p$-value $<0.1$. Estimates account for unobservable heterogeneity (Gamma distribution) 

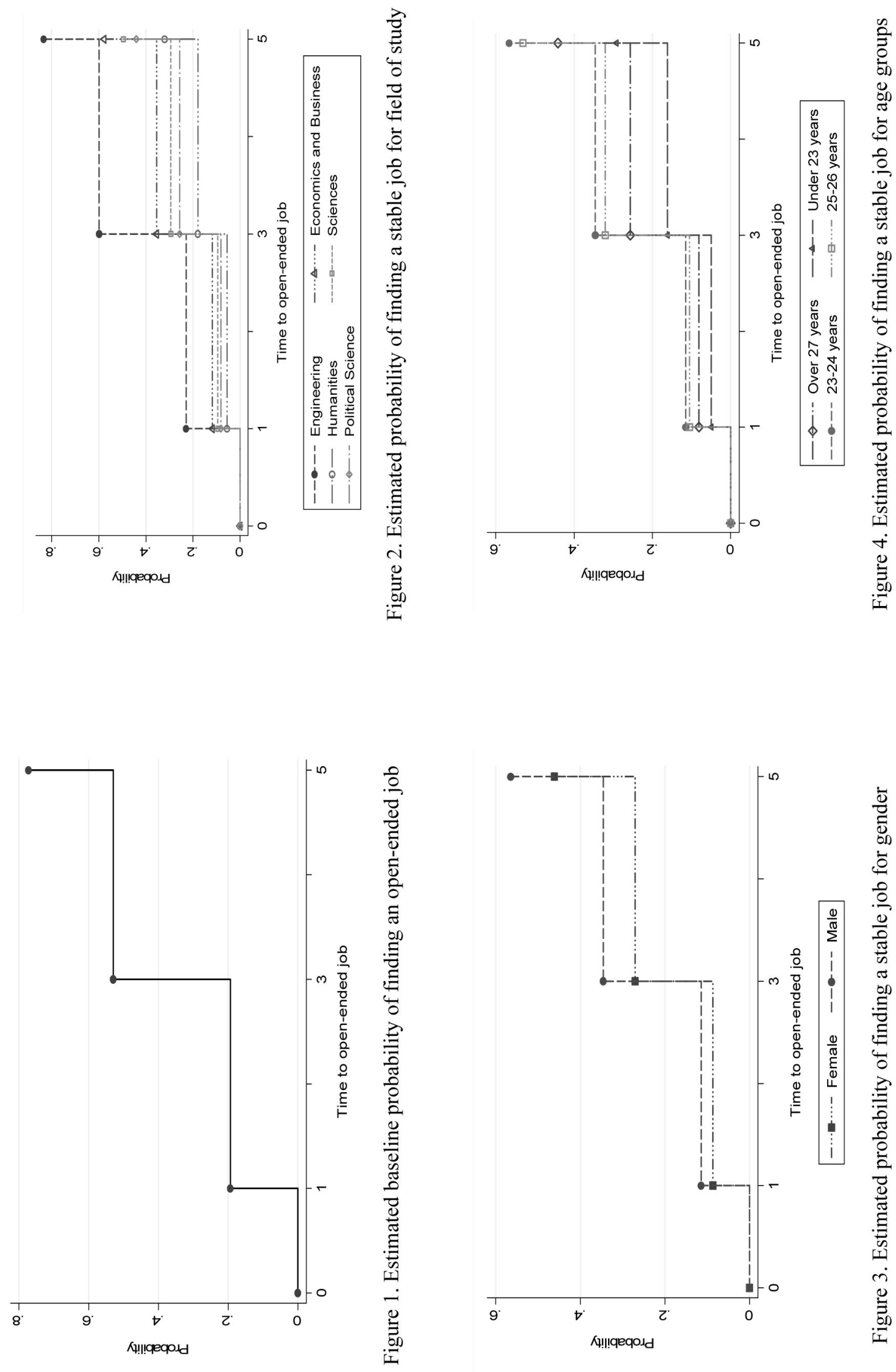

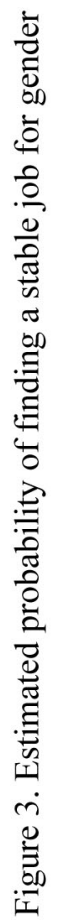

